\title{
Rose-scented geranium (Pelargonium capitatum $\times P$. radens) growth and essential oil yield response to different soil water depletion regimes
}

\author{
B.K. Eiasu, J.M. Steyn *, P. Soundy \\ Department of Plant Production and Soil Science, University of Pretoria, Pretoria 0002, South Africa
}

\section{A R T I C L E I N F O}

\section{Article history:}

Received 25 May 2008

Accepted 22 January 2009

\section{Keywords:}

Citronellol

Citronellyl formate

Essential oil composition

Fresh herbage mass

Geraniol

Maximum allowable depletion level

Plant available soil water

Water stress

\begin{abstract}
A B S T R A C T
Effective irrigation management in arid and semi-arid regions, like South Africa, could increase crop yield and thereby improve productivity of scarce fresh water resources. Experiments were conducted at the Hatfield Experimental Farm of the University of Pretoria, South Africa, from 2004 to 2006, to investigate the effect of soil water depletion regimes on rose-scented geranium (Pelargonium capitatum $\times P$. radens $\mathrm{cv}$. Rose) essential oil yield, essential oil composition and water-use efficiency in an open field and a rain shelter. Four maximum allowable soil water depletion levels (MAD), 20, 40, 60 and $80 \%$ of the plant available soil water (ASW) in the top $0.8 \mathrm{~m}$ root zone, were applied as treatments. Plant roots extracted most soil water from the top $0.4 \mathrm{~m}$ soil layer. Increasing the soil water depletion level to $60 \%$ and higher resulted in a significant reduction in herbage mass and essential oil yield. Water stress apparently increased the essential oil concentration (percentage oil on fresh herbage mass basis), but its contribution to total essential oil yield ( $\mathrm{kg} / \mathrm{ha}$ oil) was limited. Irrigation treatments did not affect essential oil composition. An increase in maximum allowable depletion level generally resulted in a decrease in leaf area and an increase in leaf to stem fresh mass ratio. Up to $28 \%$ of irrigation water could be saved by increasing maximum allowable depletion level of ASW from 20 to 40\%, without a significant reduction in essential oil yield.
\end{abstract}

(c) 2009 Elsevier B.V. All rights reserved.

\section{Introduction}

Irrigation is a major contributor to agricultural productivity. Irrigation increases land productivity by about $127 \%$, and is expected to supply half of the world's food demand by the year 2025 (Fereres and Ceňa, 1998; Qadir and Oster, 2004). Variable soil water status results in variable production, depending on the duration of the water stress and the plant growth stage (Pandey et al., 2000).

South Africa is a drought prone (mostly semi-arid) country with variable climate (Shand and Basson, 2003). Most of the fresh water resources of the country (about 60\%) are used for irrigation (Conley, 1997; Enright, 2003). Since irrigation productivity is relatively low, it is suggested that part of the water used in agriculture be transferred to other non-agricultural economic sectors to maximize water productivity (Nieuwoudt et al., 2003). Such a shift in the allocation of water resources may impose further restrictions on agricultural business, unless innovative irrigation management for each and every crop is introduced.

\footnotetext{
* Corresponding author. Tel.: +27 124203880; fax: +27 124204120 .

E-mail address: martin.steyn@up.ac.za (J.M. Steyn).
}

Rose-scented geranium (Pelargonium species) is a perennial herb that belongs to the Geraniaceae family. The plant is cultivated for its high value essential oil, which is used for production of highgrade perfumery, cosmetic products and for aromatherapy (Rajeswara Rao et al., 1996). Worldwide, annual geranium oil production is estimated to be worth about 12.5 million US dollars (Williams and Harborne, 2002). Trade in essential oils is expected to increase in the future as a result of the growing number and preferences of consumers, and the continuously widening uses of essential oil constituents (Sangwan et al., 2001).

Studies on response of rose-scented geranium essential oils to soil water have come up with different results. Rajeswara Rao et al. (1996) reported that moist seasons resulted in higher essential oil yield. A report by Singh (1999) indicated that a soil water regime of 0.6 IW to CPE (irrigation water to cumulative pan evaporation) ratio gave higher essential oil yield without a significant change in oil composition. Weiss (1997), on the other hand, reported that water stressed conditions resulted in a mild increase in oil yield. Results obtained from greenhouse pot experiments by Eiasu et al. (2008) also showed that high irrigation frequency plus a one-week withholding of irrigation prior to harvesting increased essential oil yield.

In South Africa, rose-scented geranium is produced in the Mpumalanga Lowveld, KwaZulu-Natal, Western Cape and Lim-

0378-3774/\$ - see front matter (c) 2009 Elsevier B.V. All rights reserved. doi:10.1016/j.agwat.2009.01.012 
popo provinces, usually under rainfed farming (SANDA, 2006). Weiss (1997) and Bhan et al. (2005) indicated that to date the South African geranium oil production business has not made a significant contribution to the world essential oil market. Low and erratic rainfall could be among the major contributors to the low geranium oil production in South Africa. Hence, it was hypothesised that a sound knowledge on the water requirements of rosescented geranium is indispensable to improve essential oil yield, oil composition, and water productivity. The main objective of this study was, therefore, to acquire a sound knowledge on the response of rose-scented geranium herbage growth, essential oil yield and oil composition to different soil water regimes in order to recommend effective irrigation management strategies for South Africa and other areas with similar agroclimatic conditions, where relevant experimental data are not available.

\section{Materials and methods}

\subsection{Study area and duration}

The experiments were conducted at the Hatfield Experimental Farm of the University of Pretoria, Pretoria, South Africa (Latitude $25^{\circ} 45^{\prime} \mathrm{S}$ and Longitude $28^{\circ} 16^{\prime} \mathrm{E}$, and an altitude of $1372 \mathrm{~m}$ ), from 28 October 2004 to 26 October 2006. The experimental site is situated in a region with an average annual rainfall of $670 \mathrm{~mm}$, mainly in the summer season (during the months of October-March), and monthly average maximum and minimum temperatures of about $30{ }^{\circ} \mathrm{C}$ (in January) and $1.5^{\circ} \mathrm{C}$ (in July), respectively (Annandale et al., 1999). The experiments were conducted in an open field and a rain shelter (with movable roof to screen out rainfall). Summarised data of soil chemical and physical properties of the experimental sites are presented in Tables 1 and 2, respectively.

In the open field, two parallel trials were established on the same strip of land. Trial 1 was conducted only for one growth cycle (12 March to 11 July 2005), which in Section 3 is referred to as Harvest 1. Trial 2 continued for three regrowth cycles (14 May to 13 September 2005, 14 September 2005 to 13 January 2006 and 26 June to 25 October 2006, for the 1st, 2nd and 3rd regrowth cycles, respectively). In Section 3, the data from the 1st, 2nd and 3rd regrowth cycles of Trial 2 are referred to as Harvests 2, 3 and 4, respectively. The experiment in the rain shelter was conducted for two regrowth cycles, from 27 February to 26 June 2006 and from 27 June to 26 October 2006 (Rain shelter Harvests 1 and 2, respectively).

\subsection{Plant culture}

Rose-scented geranium is commonly raised from stem cuttings. At commercial level, it takes five to six months from planting to the first harvest. Duration for the subsequent regrowth cycles (from

Table 1

Soil chemical properties of the top $0.3 \mathrm{~m}$ soil depths of the experimental sites.

\begin{tabular}{|c|c|c|}
\hline Parameter & Open field & Rain shelter \\
\hline $\begin{array}{l}\text { Electrical conductance (Saturation paste method) } \\
\quad(\mathrm{dS} / \mathrm{m})\end{array}$ & 0.5 & 0.45 \\
\hline $\mathrm{pH}(1: 2.5$ soil:water $)$ & 5.1 & 5.2 \\
\hline Iron (Fe) (EDTA extraction method) (mg/kg) & 71.1 & 67.2 \\
\hline $\mathrm{NH}_{4}^{+}(1: 2$ soil: $1 \mathrm{M} \mathrm{KCl})(\mathrm{mg} / \mathrm{kg})$ & 4.0 & 3.5 \\
\hline $\mathrm{NO}_{3}^{-}(50 \mathrm{~g}$ soil: $100 \mathrm{ml} 1 \mathrm{M} \mathrm{KCl})(\mathrm{mg} / \mathrm{kg})$ & 6.1 & 5.3 \\
\hline Phosphorus (P) (Bray I method) (mg/kg) & 28.2 & 29.0 \\
\hline Potassium (K) (Ammonium acetate extractable) (mg/kg) & 73.0 & 65.0 \\
\hline $\begin{array}{l}\text { Sodium (Na) (Ammonium acetate extractable) } \\
(\mathrm{mg} / \mathrm{kg})\end{array}$ & 31.0 & 21.0 \\
\hline Calcium (Ca) (Ammonium acetate extractable) ( $\mathrm{mg} / \mathrm{kg}$ ) & 190.0 & 186.0 \\
\hline $\begin{array}{l}\text { Magnesium (Mg) (Ammonium acetate extractable) } \\
(\mathrm{mg} / \mathrm{kg})\end{array}$ & 42.0 & 44.0 \\
\hline
\end{tabular}

Table 2

Physical properties for the different soil layers of the experimental sites.

\begin{tabular}{|c|c|c|c|c|c|c|c|}
\hline \multirow[t]{2}{*}{$\begin{array}{l}\text { Soil depth } \\
\text { (m) }\end{array}$} & \multicolumn{3}{|c|}{$\begin{array}{l}\text { Particle size } \\
\text { distribution (\%) }\end{array}$} & \multirow[t]{2}{*}{$\begin{array}{l}\text { Bulk density } \\
\left(\mathrm{Mg} / \mathrm{m}^{3}\right)\end{array}$} & \multicolumn{3}{|c|}{ Water content (mm) } \\
\hline & Clay & Silt & Sand & & Field capacity & $\mathrm{PWP}^{\mathrm{a}}$ & $\mathrm{ASW}^{\mathrm{b}}$ \\
\hline \multicolumn{8}{|l|}{ Open field } \\
\hline $0.0-0.2$ & 20.1 & 13.1 & 66.8 & 1.42 & 40.4 & 20.4 & 20.0 \\
\hline $0.2-0.4$ & 24.2 & 12.5 & 63.3 & 1.64 & 50.2 & 22.0 & 28.2 \\
\hline $0.4-0.6$ & 26.6 & 10.3 & 63.1 & 1.48 & 48.0 & 23.8 & 24.2 \\
\hline $0.6-0.8$ & 28.4 & 14.5 & 57.1 & 1.49 & 53.4 & 26.0 & 27.4 \\
\hline Total & & & & & 192.0 & 92.0 & 100.0 \\
\hline \multicolumn{8}{|c|}{ Rain shelter } \\
\hline $0.0-0.2$ & 23.2 & 10.3 & 56.5 & 1.45 & 52.2 & 26.2 & 26.2 \\
\hline $0.2-0.4$ & 28.2 & 11.3 & 60.5 & 1.61 & 59.6 & 29.6 & 29.6 \\
\hline $0.4-0.6$ & 27.1 & 13.2 & 59.7 & 1.43 & 54.0 & 26.0 & 26.0 \\
\hline $0.6-0.8$ & 26.5 & 12.2 & 61.3 & 1.49 & 53.6 & 25.2 & 25.2 \\
\hline Total & & & & & 219.4 & 112.4 & 107.0 \\
\hline
\end{tabular}

a PWP: permanent wilting point.

b ASW: plant available soil water.

cut back to harvesting of regenerated shoots) is three to four months. Once the crop is established, it could be harvested for up to 10 years (Weiss, 1997).

In the current experiments, rose-scented geranium (Pelargonium capitatum $\times P$. radens $\mathrm{cv}$. Rose) was used as plant material. For the open field trials, about 45 day old plantlets, which were propagated from stem cuttings by a commercial nursery, were transplanted on 28 October 2004. For the rain shelter trial, healthy stem cuttings (taken from the open field trials) were planted in seedling trays filled with peat on 25 August 2005, and raised at high relative humidity (in a mist bed) in a greenhouse at the Hatfield Experimental Farm. Plantlets were transplanted on 01 October 2005. For both sites (the open field and the rain shelter), the plants were allowed to grow for about seven months until uniform establishment, whereafter they were cut back to start the irrigation treatments. Thus, all data were recorded on regrowths only. A regrowth duration of four months was decided on, according to local commercial farmer practices.

\subsection{Treatments and design}

\subsubsection{Experimental layout}

In both the open field trials, each experimental area was divided into four blocks (replications). Each block consisted of four plots of $7.5 \mathrm{~m}$ long and $5 \mathrm{~m}$ wide. There was a buffer strip of $1.5 \mathrm{~m}$ between two adjacent blocks. Spacing between adjacent rows was $1 \mathrm{~m}$, and plants in a row were planted $0.6 \mathrm{~m}$ apart. Each experimental plot consisted of five rows, and data recording was done on the three middle rows.

The area in the rain shelter was also divided into four blocks (replications). A higher plant density $(0.75 \mathrm{~m}$ inter-row and $0.45 \mathrm{~m}$ intra-row spacing) was applied to ensure sufficient plant material from the smaller plots ( $6 \mathrm{~m}$ long and $3 \mathrm{~m}$ wide). To avoid movement of water between plots and plant roots growing into adjacent plots of different treatments, plastic sheets were installed vertically between plots to a depth of $0.8 \mathrm{~m}$. Each experimental plot comprised of four rows. In all trials, treatments were arranged in a randomized complete block design (RCBD) with four replications.

\subsubsection{Treatments}

Irrigation treatments were scheduled based on maximum allowable depletion (MAD) percentage of the plant available soil water (ASW). The predefined treatments applied were 20, 40, 60 and $80 \%$ MAD of ASW. No water stress was applied in the first month of each regrowth cycle to limit plant mortalities. Cultural 
practices such as fertilizer application and hoeing were applied within this period. Irrigation treatments were imposed during the remaining three months of each regrowth cycle. During establishment (or when recovering from cutting, in the first month of each regrowth cycle), all experimental plots were irrigated when $20 \%$ of ASW was depleted.

\subsubsection{Irrigation monitoring}

The experimental plots were irrigated when the respective MAD threshold values for each treatment were reached. A neutron probe (Model 503 DR, CPN Corporation, CA, USA) was used to measure soil water content. Neutron probe readings (at intervals of $0.2 \mathrm{~m}$, to a soil depth of $1.2 \mathrm{~m}$ ) were taken on every alternative day. A computer controlled pressure-compensated drip irrigation system, with water discharge rate of $1.64 \mathrm{l} / \mathrm{h}$ at pressure range of 150-200 kPa (NETAFIM, Cape Town, South Africa) was used in both experiments. The drip lines were placed $0.5 \mathrm{~m}$ apart, and the in-line spacing between dripper emitters was $0.3 \mathrm{~m}$. The percentage depletion of ASW $\left(\theta_{d}\right)$ and the volume of irrigation water $\left(V_{I}\right)$ required $\left(\mathrm{m}^{3} / \mathrm{plot}\right)$ to refill the root zone to field capacity were calculated as:

$\theta_{\mathrm{d}}=100 \times \frac{1}{n} \sum_{i}^{n} \frac{\theta_{F C i}-\theta_{i}}{\theta_{F C i}-\theta_{P W P i}}$

$V_{\mathrm{I}}=\theta_{\mathrm{d}} R_{\mathrm{z}} A\left(\frac{1}{100}\right)$

Table 3

Days of regrowth cycle and amount of irrigation applied to treatments in the open field.

\begin{tabular}{|c|c|c|c|c|c|c|c|c|}
\hline \multirow[t]{3}{*}{ Experimental duration } & \multicolumn{8}{|c|}{ Irrigation treatments } \\
\hline & \multicolumn{2}{|c|}{$20 \% \mathrm{MAD}^{\mathrm{a}}$} & \multicolumn{2}{|c|}{$40 \% \mathrm{MAD}$} & \multicolumn{2}{|c|}{$60 \% \mathrm{MAD}$} & \multicolumn{2}{|c|}{$80 \% \mathrm{MAD}$} \\
\hline & Day & Amount (mm) & Day & Amount (mm) & Day & Amount (mm) & Day & Amount (mm) \\
\hline \multirow[t]{20}{*}{12 March-11 July 2005 (Harvest 1) } & 1 & 20.5 & 5 & 21.5 & 1 & 20.2 & 3 & 19.3 \\
\hline & 9 & 20.3 & 13 & 20.7 & 7 & 20.2 & 11 & 20.5 \\
\hline & 15 & 20.7 & 19 & 18.0 & 13 & 19.7 & 17 & 19.2 \\
\hline & 21 & 19.7 & 25 & 19.0 & 19 & 18.1 & 23 & 18.8 \\
\hline & 27 & 18.6 & 31 & 17.0 & 25 & 18.3 & 29 & 19.7 \\
\hline & 33 & 16.1 & 45 & 37.1 & 31 & 18.0 & 85 & 75.2 \\
\hline & 39 & 16.8 & 61 & 38.4 & 57 & 56.1 & & \\
\hline & 45 & 18.1 & 77 & 37.1 & 81 & 56.6 & & \\
\hline & 51 & 18.9 & 91 & 37.4 & 113 & 56.7 & & \\
\hline & 57 & 19.6 & 105 & 37.2 & & & & \\
\hline & 63 & 19.2 & 117 & 37.0 & & & & \\
\hline & 69 & 18.1 & & & & & & \\
\hline & 75 & 18.2 & & & & & & \\
\hline & 81 & 19.1 & & & & & & \\
\hline & 87 & 19.1 & & & & & & \\
\hline & 93 & 18.9 & & & & & & \\
\hline & 99 & 18.6 & & & & & & \\
\hline & 105 & 17.4 & & & & & & \\
\hline & 111 & 18.8 & & & & & & \\
\hline & 117 & 18.8 & & & & & & \\
\hline \multirow[t]{17}{*}{14 May-13 September 2005 (Harvest 2) } & 5 & 19.1 & 5 & 19.7 & 5 & 19.1 & 5 & 21.6 \\
\hline & 11 & 20.8 & 11 & 20.7 & 11 & 20.5 & 11 & 20.7 \\
\hline & 17 & 20.0 & 17 & 19.2 & 17 & 18.3 & 17 & 21.5 \\
\hline & 23 & 19.8 & 23 & 20.0 & 23 & 18.2 & 23 & 20.3 \\
\hline & 29 & 22.5 & 29 & 18.6 & 29 & 20.7 & 29 & 17.9 \\
\hline & 37 & 21.0 & 49 & 39.8 & 61 & 55.9 & 101 & 77.0 \\
\hline & 43 & 20.0 & 63 & 36.4 & 81 & 56.2 & & \\
\hline & 49 & 20.5 & 81 & 38.8 & & & & \\
\hline & 61 & 21.5 & 95 & 35.9 & & & & \\
\hline & 67 & 20.7 & 107 & 39.8 & & & & \\
\hline & 75 & 19.7 & & & & & & \\
\hline & 81 & 19.5 & & & & & & \\
\hline & 87 & 20.6 & & & & & & \\
\hline & 93 & 18.9 & & & & & & \\
\hline & 99 & 20.3 & & & & & & \\
\hline & 105 & 19.3 & & & & & & \\
\hline & 113 & 18.8 & & & & & & \\
\hline
\end{tabular}

\footnotetext{
a MAD: maximum allowable depletion of plant available soil water.
}

where $\theta_{F C i}$ represents volumetric soil water content $\left(\mathrm{m}^{3} / \mathrm{m}^{3}\right)$ at field capacity for the $i$ th layer, $\theta_{i}$ (measured) volumetric soil water content $\left(\mathrm{m}^{3} / \mathrm{m}^{3}\right)$ of the $i$ th layer, $\theta_{P W P i}$ volumetric soil water content at permanent wilting point $\left(\mathrm{m}^{3} / \mathrm{m}^{3}\right)$ in the $i$ th layer, $n$ total number of layers under consideration, $A$ area of plots $\left(\mathrm{m}^{2}\right)$, and $R_{\mathrm{z}}$ effective root zone depth $(0.8 \mathrm{~m}$, in this case).

Based on preliminary observations of soil water depletion from the root zone during the six months of plant establishment, effective plant root zone was considered to be the top $0.8 \mathrm{~m}$ soil layer. In the rain shelter, rainfall was successfully excluded. In the open field, precipitation depth that exceeded the ASW deficit in the $0.8 \mathrm{~m}$ root zone under consideration was considered as deep percolation or runoff, and was excluded from effective evapotranspiration calculations. Evapotranspiration (ET) for each regrowth cycle was calculated as:

$\mathrm{ET}=P+I-(D+R) \pm \Delta W$

where $P, I, D, R$ and $\Delta W$ represent effective rainfall ( $\mathrm{mm}$ ), irrigation water applied $(\mathrm{mm})$, water lost by deep percolation $(\mathrm{mm})$, surface runoff $(\mathrm{mm})$ and change in soil water storage (soil water content at the beginning of the experiment minus soil water content at harvesting), respectively.

\subsection{Data recorded}

During harvesting, plant shoots were cut to a height of about $0.15-0.20 \mathrm{~m}$ above ground. Herbage fresh mass was measured 
immediately after cutting. Leaf area was measured using an LI 3100 belt driven leaf area meter (LiCor, Lincoln, NE, USA), and leaf area index was determined by dividing the leaf area by the harvested land area. The samples were oven-dried at about $70{ }^{\circ} \mathrm{C}$ to a constant mass to determine the respective dry matter contents.

Freshly harvested herbage samples (of about 5-7 kg each) were taken for essential oil content determination. Essential oil was extracted by steam distillation technique using a $90 \mathrm{~kg}$ capacity custom-built distillation device Model KSST (Riebeek Kasteel 7306, Grahamstown, South Africa). From the essential oil content, the oil yield per treatment was determined.

Oil composition analyses were done on oil samples that were pooled per treatment. The pooling was accomplished by thoroughly mixing equal amounts of oil from each of the four replications of the same treatment. For gas chromatography (GC) oil analysis, an Agilent GC (FID) model 6890N (Agilent Technologies, Inc., Santa Clara, CA), fitted with $30 \mathrm{~m} \times 0.25 \mathrm{~mm}$ fused silica capillary column and a film thickness of $0.25 \mu \mathrm{m}$, was used. Helium gas was used as a carrier. The temperature programme was 50-200 ${ }^{\circ} \mathrm{C}$ with ramp amount of $5{ }^{\circ} \mathrm{C} \mathrm{min}^{-1}$, and a detector and an injector temperature of $220^{\circ} \mathrm{C}$. Constituents were identified based on their retention time as previously determined with pure chemicals as standards (Adams, 2004). The recorded data were subjected to analysis of variance (ANOVA) using MSTAT-C, a data analysing microcomputer programme (MSTAT-C, 1991). Where applicable, treatment means were compared using the least significant difference (LSD) test at 0.05 probability level.

\section{Results and discussion}

\subsection{Irrigation applied and soil water depletion patterns}

Irrigation days and amounts (depths) of water applied to refill the root zone to field capacity for each treatment are presented in Tables 3 and 4. The 20\% MAD treatment was irrigated 15 times during the treatment application period (from about day 30 until the end of each regrowth cycle), while the $80 \%$ MAD treatment was irrigated only once. The irrigation depth per irrigation event ranged from about 18 to $22 \mathrm{~mm}$ (for the 20\% MAD treatment) to about $75-85 \mathrm{~mm}$ (for the $80 \%$ MAD treatment).

Examples of the depth-wise temporal soil water variation in the root zone for the irrigation treatments are presented in Figs. 1 and 2 . For clarity, only the soil water contents recorded during the last three months of regrowth cycles (when irrigation treatments were applied) are shown in the figures. Soil water depletion rate was higher in the top $0.2 \mathrm{~m}$ soil layer, where the density of fine roots is commonly highest (Goldhamer et al., 1999), than in the subsoil.

As the irrigation interval became longer (higher MAD percentage), the top $0.2 \mathrm{~m}$ soil layer dried out more, and the proportion of water taken up from the deeper soil layers increased. The water content of the top $0.2 \mathrm{~m}$ soil layer dropped below permanent

Table 4

Days of regrowth cycle and amount of irrigation applied to treatments in the rain shelter.

\begin{tabular}{|c|c|c|c|c|c|c|c|c|}
\hline \multirow[t]{3}{*}{ Experimental duration } & \multicolumn{8}{|c|}{ Irrigation treatments } \\
\hline & \multicolumn{2}{|c|}{$20 \% \mathrm{MAD}^{\mathrm{a}}$} & \multicolumn{2}{|c|}{$40 \% \mathrm{MAD}$} & \multicolumn{2}{|c|}{$60 \% \mathrm{MAD}$} & \multicolumn{2}{|c|}{$80 \%$ MAD } \\
\hline & Day & Amount (mm) & Day & Amount (mm) & Day & Amount (mm) & Day & Amount (mm) \\
\hline \multirow[t]{17}{*}{27 February-26 June 2006 (Harvest 1) } & 1 & 21.7 & 3 & 20.9 & 3 & 21.4 & 5 & 22.0 \\
\hline & 9 & 17.3 & 11 & 22.2 & 13 & 26.0 & 13 & 23.4 \\
\hline & 11 & 21.1 & 19 & 26.9 & 21 & 22.0 & 21 & 22.0 \\
\hline & 19 & 21.0 & 27 & 21.2 & 29 & 24.5 & 29 & 22.0 \\
\hline & 29 & 20.9 & 47 & 42.2 & 63 & 64.3 & 91 & 85.0 \\
\hline & 39 & 19.3 & 65 & 43.7 & 91 & 64.0 & & \\
\hline & 51 & 20.6 & 81 & 42.4 & 119 & 64.3 & & \\
\hline & 59 & 20.7 & 97 & 43.6 & & & & \\
\hline & 67 & 21.0 & 111 & 43.2 & & & & \\
\hline & 77 & 22.3 & & & & & & \\
\hline & 83 & 20.9 & & & & & & \\
\hline & 89 & 22.0 & & & & & & \\
\hline & 95 & 21.8 & & & & & & \\
\hline & 101 & 21.1 & & & & & & \\
\hline & 107 & 21.6 & & & & & & \\
\hline & 113 & 19.6 & & & & & & \\
\hline & 119 & 21.9 & & & & & & \\
\hline \multirow[t]{19}{*}{27 June-26 October 2006 (Harvest 2) } & 1 & 22.2 & 3 & 21.4 & 1 & 21.5 & 5 & 19.0 \\
\hline & 9 & 21.7 & 13 & 23.4 & 9 & 20.6 & 13 & 21.9 \\
\hline & 17 & 21.4 & 21 & 22.5 & 11 & 23.0 & 21 & 25.9 \\
\hline & 23 & 21.2 & 29 & 21.8 & 21 & 22.2 & 27 & 24.2 \\
\hline & 29 & 20.5 & 45 & 42.3 & 29 & 24.7 & 79 & 85.3 \\
\hline & 37 & 22.3 & 59 & 42.5 & 63 & 63.5 & & \\
\hline & 43 & 20.6 & 77 & 43.1 & 95 & 64.3 & & \\
\hline & 49 & 19.2 & 93 & 42.4 & & & & \\
\hline & 55 & 21.1 & 107 & 42.2 & & & & \\
\hline & 61 & 21.0 & & & & & & \\
\hline & 67 & 20.3 & & & & & & \\
\hline & 73 & 21.4 & & & & & & \\
\hline & 79 & 21.5 & & & & & & \\
\hline & 85 & 20.7 & & & & & & \\
\hline & 91 & 20.0 & & & & & & \\
\hline & 97 & 20.6 & & & & & & \\
\hline & 103 & 20.8 & & & & & & \\
\hline & 109 & 21.0 & & & & & & \\
\hline & 117 & 22.6 & & & & & & \\
\hline
\end{tabular}

a MAD: maximum allowable depletion of plant available soil water. 

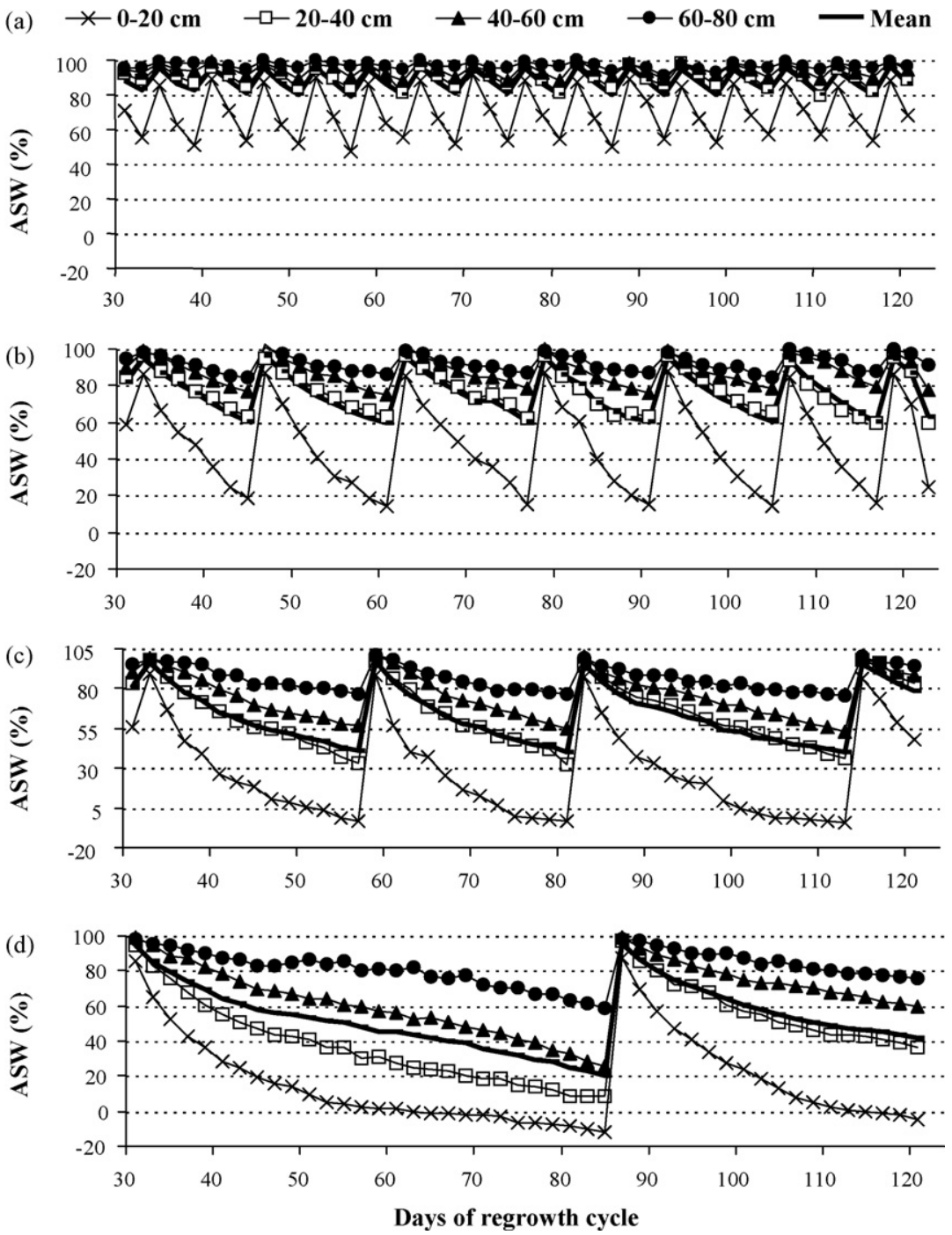

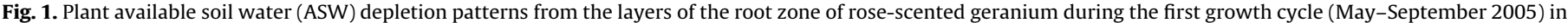
the open field for the $20 \%$ (a), $40 \%$ (b), $60 \%$ (c), and $80 \%$ (d) maximum allowable depletion (MAD) treatments.

wilting point by the time that the depletion threshold level was reached for the $80 \%$ MAD treatment. This could be attributed to direct evaporation of water from the topsoil, since it was unlikely for the root system to extract water at such a very low water potential (Laio et al., 2001).

Data presented in Table 5 show that in the 20\% MAD treatment, about $78-80 \%$ of the total water was depleted from the top $0.4 \mathrm{~m}$ root zone. This could be associated with higher soil evaporation due to frequent wetting and a denser root system closer to the soil surface (Goldhamer et al., 1999; Tufekcioglu et al., 1999; Panda et al., 2004). In the $80 \%$ MAD treatment, more water was taken up from the 0.4 to $0.8 \mathrm{~m}$ soil layer and as a result, the proportion of the water depleted from the top $0.4 \mathrm{~m}$ soil layer dropped to between 61 and $66 \%$.

In general, water depletion rate progressively declined as the soil water depletion level approached the set threshold value for the $80 \%$ MAD treatment, even though the plant ASW status in the $0.6-0.8 \mathrm{~m}$ root zone was still above $55 \%$. This illustrated that the distal roots of rose-scented geranium were less effective in taking up water than the proximal roots.

\subsection{Herbage yield parameters}

Fig. 3 shows that the lower the MAD level, the better the herbage yield. In most cases, water stress effects on herbage yield became evident when more than $40 \%$ of the ASW was depleted, proving that high soil water encourages herbage yield (Rajeswara Rao et al., 1996; Eiasu et al., 2008). Hence, for higher herbage yield of rose-scented geranium, the ASW in the effective root zone should be maintained above $60 \%$, which is close to the soil water level (55-65\% of soil water at field capacity) previously recommended for this crop (Weiss, 1997).

The markedly high herbage yield differences between harvests could probably be attributed to seasonal variations. Herbage yields of Harvest 3 in the open field (Fig. 3a) and Harvest 1 in the rain shelter (Fig. 3b), of regrowths during higher temperature seasons (summer and spring, respectively), were highest. On the other hand, the herbage yields obtained from the other harvests, which experienced cool regrowth seasons (end of autumn, winter and/or beginning of spring), were lower. These results are in agreement with previous work that characterized rose-scented geranium as a warm to hot season crop (Weiss, 1997; Lis-Balchin, 2002).

Leaf area index (LAI) and fresh leaf mass ratio (as a percentage of the total fresh herbage mass) data are presented in Table 6. In most of the harvests, LAI was significantly reduced when 60 or $80 \%$ MAD level was applied. To the contrary, leaf mass to total fresh herbage mass ratio increased with an increase in maximum allowable depletion level. Hence, the highest and lowest values were recorded for the 80 and 20\% MAD level treatments, 

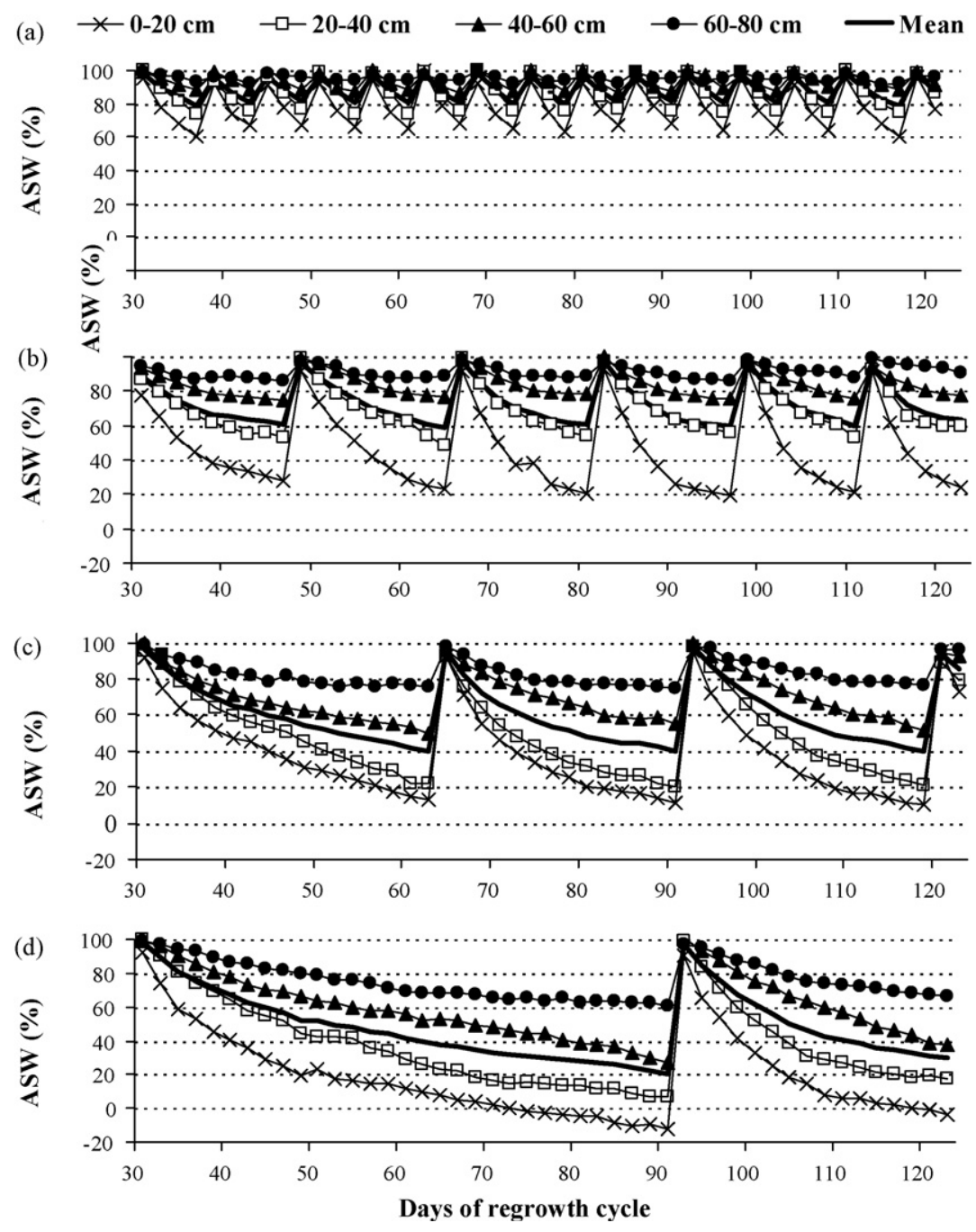

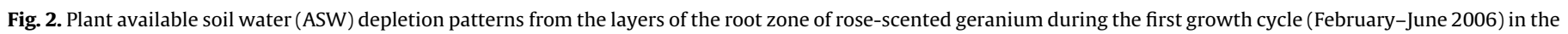
rain shelter for the $20 \%$ (a), $40 \%$ (b), $60 \%$ (c), and $80 \%$ (d) maximum allowable depletion (MAD) treatments.

respectively. This could be explained by lower water content in the stem under water stressed conditions, as opposed to the succulent nature of pelargonium stems observed under well-watered conditions (Jones et al., 2003). Results presented in Table 7 show that leaf and stem dry matter contents (\%) tended to increase with an increase in MAD level. Within the same treatments and the same harvests, leaf dry matter content was consistently higher than stem dry matter content, confirming the succulent characteristics of stems in Pelargonium species.

Table 5

Average amounts of water applied to refill the soil profile and percentage ASW depletion per soil layer for different irrigation regime treatments in the open field and rain shelter trials.

\begin{tabular}{|c|c|c|c|c|c|c|c|c|c|}
\hline \multirow[t]{2}{*}{ Trial site } & \multirow[t]{2}{*}{ Soil depth (m) } & \multicolumn{2}{|c|}{$20 \% \mathrm{MAD}^{\mathrm{a}}$} & \multicolumn{2}{|c|}{$40 \% \mathrm{MAD}$} & \multicolumn{2}{|c|}{$60 \% \mathrm{MAD}$} & \multicolumn{2}{|c|}{$80 \%$ MAD } \\
\hline & & $\%$ & $\mathrm{~mm}$ & $\%$ & $\mathrm{~mm}$ & $\%$ & $\mathrm{~mm}$ & $\%$ & \\
\hline \multirow[t]{4}{*}{ Open field } & $0.0-0.2$ & 49.8 & 10.2 & 86.3 & 17.6 & 100.6 & 20.5 & 109.8 & \\
\hline & $0.2-0.4$ & 17.9 & 5.0 & 37.3 & 10.5 & 72.2 & 20.4 & 89.9 & \\
\hline & $0.4-0$ & 9.4 & 2.3 & 22.0 & 5.3 & 42.1 & 10.2 & 73.6 & \\
\hline & $0.6-0.8$ & 5.3 & 1.5 & 13.0 & 3.6 & 23.3 & 6.4 & 43.8 & \\
\hline \multirow[t]{4}{*}{ Rain shelter } & $0.0-$ & 35.4 & 9.3 & 76.4 & 20.0 & 92.9 & 24.3 & 110.9 & \\
\hline & 0. & 25.0 & 7.4 & 46.1 & 13.6 & 77.7 & 23.0 & 93.8 & \\
\hline & $0.4-$ & 11.7 & 3.0 & 25.7 & 6.7 & 46.8 & 12.2 & 72.3 & \\
\hline & $0.6-0.8$ & 6.2 & 1.6 & 11.6 & 2.9 & 22.0 & 5.5 & 41.3 & 10 \\
\hline
\end{tabular}

${ }^{a}$ MAD: maximum allowable depletion of plant available soil water.

\subsection{Oil yield parameters}

In all harvests, essential oil yield showed a significant decline when irrigation was scheduled at 60 and $80 \%$ MAD of ASW (Fig. 4). This proves that essential oil yield is positively related to soil water status and herbage growth (Singh et al., 1996). In agreement with these results, Kumar et al. (2001) and Motsa et al. (2006) reported that higher herbage yield resulted in higher total essential oil yield.

Depending on cultivar and number of possible harvests, geranium oil yield ranges between 5 and $20 \mathrm{~kg} / \mathrm{h}$ a per year (Weiss, 1997). In South African rose-scented geranium production, three harvests per year are possible. In this study two consecutive harvests over an eight-month growth period (Harvests 2 and 3 for the open field trial) yielded a total of about 53 and $42 \mathrm{~kg} / \mathrm{ha}$ oil for the 20 and $40 \%$ MAD treatments, respectively. Hence, the essential oil yields obtained in the current study can be considered above average.

In the open field, the effect of MAD treatments on oil content (percentage oil on fresh herbage mass basis) was not consistent (Fig. 5a). In the rain shelter, oil content showed increasing trends as the MAD level increased (Fig. 5b). However, the apparent increase in oil content at the higher MAD levels was not sufficient to compensate for the oil yield ( $\mathrm{kg} / \mathrm{ha})$ loss due to reduction in herbage yield. Kumar et al. (2001) also reported that the 

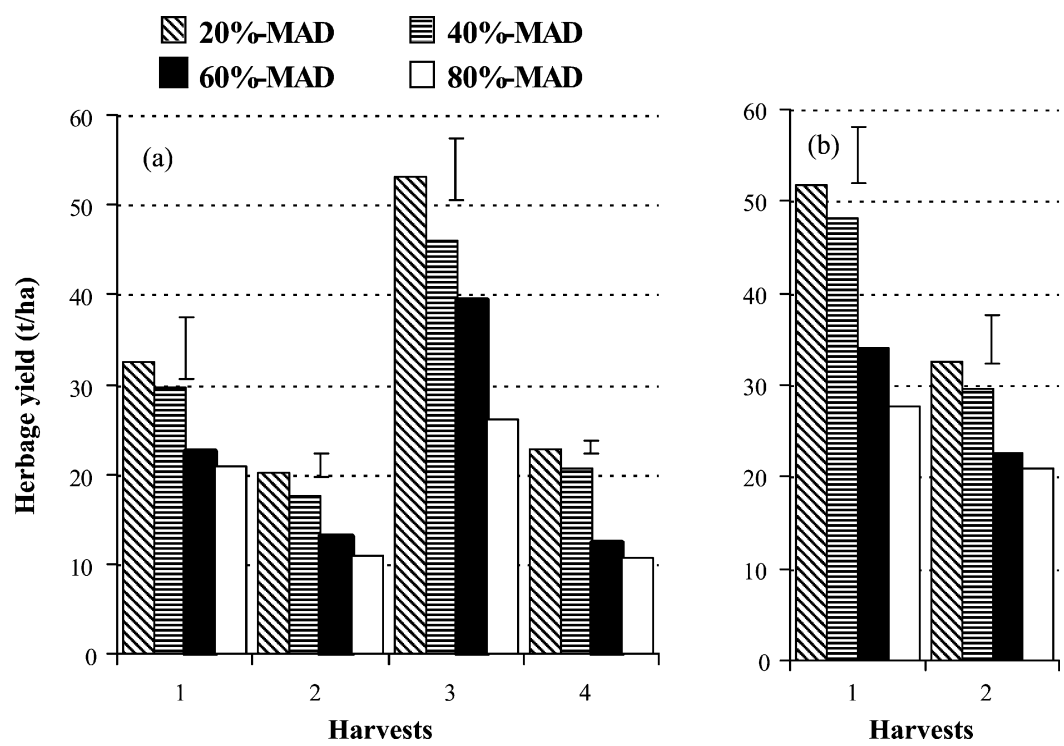

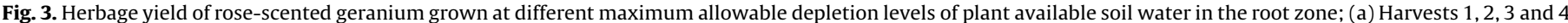

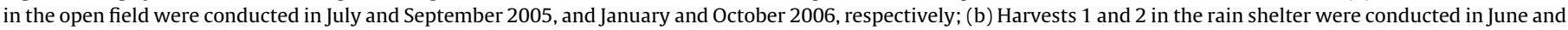
October 2006, respectively; vertical bars are LSD (at $P<0.05$ ).

contribution of essential oil content to essential oil yield was negligible, compared to the contribution made by herbage yield.

In the chromatographic oil analyses, only the first seven principal components were considered (Fig. 6). The results indicated that percentage composition of the seven major components was not significantly affected by soil water level. Similar to our results, Singh et al. (1996) documented that essential oil composition did not respond to amount of irrigation.

Prominent oil composition variations were, however, observed among harvests. Geraniol content tended to increase with a decrease in citronellol and citronellyl formate contents for Harvests 1-3. Rajeswara Rao et al. (1996) found similar results and suggested that geraniol was converted into citronellol with

\section{Table 6}

Leaf area index (LAI) and fresh leaf mass ratio (as a percentage of the total fresh herbage mass) for rose-scented geranium grown at different maximum allowable depletion levels of plant available soil water, recorded at harvest.

\begin{tabular}{|c|c|c|c|c|c|c|}
\hline \multirow[t]{2}{*}{$\mathrm{MAD}^{\mathrm{a}}$} & \multicolumn{4}{|c|}{ Open field ${ }^{\mathrm{b}}$} & \multicolumn{2}{|c|}{ Rain shelter $^{c}$} \\
\hline & Harvest 1 & Harvest 2 & Harvest 3 & Harvest 4 & Harvest 1 & Harvest 2 \\
\hline \multicolumn{7}{|l|}{ LAI } \\
\hline $20 \%$ & $3.62 \mathrm{a}^{\mathrm{d}}$ & $1.93 \mathrm{a}$ & $5.89 \mathrm{a}$ & $2.79 \mathrm{a}$ & $6.70 \mathrm{a}$ & $6.05 \mathrm{a}$ \\
\hline $40 \%$ & $2.62 \mathrm{~b}$ & $1.73 \mathrm{a}$ & $5.78 \mathrm{a}$ & $2.54 \mathrm{~b}$ & 6.62 a & $5.65 \mathrm{a}$ \\
\hline $60 \%$ & $1.94 \mathrm{bc}$ & $1.39 \mathrm{~b}$ & $4.79 \mathrm{~b}$ & $1.62 \mathrm{c}$ & $4.99 \mathrm{~b}$ & $4.14 \mathrm{c}$ \\
\hline $80 \%$ & $1.60 \mathrm{c}$ & $1.25 \mathrm{~b}$ & $3.66 \mathrm{c}$ & $1.38 \mathrm{~d}$ & $4.31 \mathrm{~b}$ & $3.31 \mathrm{~d}$ \\
\hline Grand mean & 2.44 & 1.58 & 5.03 & 2.08 & 5.65 & 4.79 \\
\hline CV (\%) & 24.80 & 10.83 & 8.74 & 6.69 & 7.79 & 9.50 \\
\hline $\operatorname{LSD}(P<0.05)$ & 0.96 & 0.27 & 0.70 & 0.22 & 0.70 & 0.72 \\
\hline \multicolumn{7}{|c|}{ Fresh leaf mass (as percentage of total fresh herbage mass) } \\
\hline $20 \%$ & $62.37 \mathrm{c}$ & $69.82 \mathrm{a}$ & $61.11 c$ & $63.01 \mathrm{~b}$ & $62.32 \mathrm{c}$ & $60.41 \mathrm{c}$ \\
\hline $40 \%$ & $63.88 \mathrm{c}$ & $71.57 \mathrm{~b}$ & $62.76 \mathrm{c}$ & $63.48 \mathrm{~b}$ & $62.77 \mathrm{c}$ & $62.83 \mathrm{~b}$ \\
\hline $60 \%$ & $66.54 \mathrm{~b}$ & $72.56 \mathrm{~b}$ & $65.18 \mathrm{~b}$ & $67.01 \mathrm{a}$ & $63.94 \mathrm{~b}$ & $63.80 \mathrm{~b}$ \\
\hline $80 \%$ & $69.07 \mathrm{a}$ & $75.84 \mathrm{a}$ & 70.92 a & $69.24 \mathrm{a}$ & 66.05 a & 65.59 a \\
\hline Grand mean & 65.46 & 72.44 & 64.99 & 65.68 & 63.77 & 63.15 \\
\hline $\mathrm{CV}(\%)$ & 2.02 & 1.36 & 1.82 & 2.24 & 1.15 & 1.18 \\
\hline $\operatorname{LSD}(P<0.05)$ & 2.11 & 1.57 & 1.89 & 2.54 & 1.17 & 1.19 \\
\hline
\end{tabular}

a MAD: maximum allowable depletion of plant available soil water.

b Harvests 1, 2, 3 and 4 in the open field trials were conducted in July and September 2005, and January and October 2006, respectively.

c Harvests 1 and 2 in the rain shelter were conducted in June and October 2006, respectively.

d Values in a column followed by the same letter do not differ significantly at $P<0.05$. time in rose-scented geranium. Luthra et al. (1991), on the other hand, reported a positive correlation between geraniol and citronellol in Cymbopogon winterianus.

The present results showed that the seven major essential oil components comprised $77.2 \pm 2.9 \%$ of the total essential oil recovered by steam distillation. Citronellol was the dominant component $(32.6 \pm 4 \%)$ and linalool $(0.59 \pm 0.2 \%)$ content was lowest. Citronellol to geraniol ratio varied among harvests (15.2, 3.7 and 2.2 for Harvests 1,2 and 3, respectively). The extremely high citronellol to geranium ratio for Harvest 1 is not preferred by the perfumery industry. Although a citronellol to geranium ratio in the range of one to three is acceptable, the most desirable in the perfumery and fragrance industries is a ratio of one (Motsa et al., 2006).

\subsection{Water use and water-use efficiency}

The current results revealed that rose-scented geranium uses more water when it is irrigated more frequently, since in all the experiments the highest water use was recorded for the 20\% MAD irrigation schedule (Table 8). In such situations, more water is lost through evapotranspiration, but dry matter production does not always increase proportionally (Salisbury and Ross, 1992; Lambers et al., 1998), resulting in lower WUE.

There was no consistent proof that water stress improved WUE. In terms of essential oil production, WUE did not show a consistent trend in the open field trial. For both regrowth cycles in the rain shelter, however, the highest WUE in terms of oil yield was recorded for the $80 \%$ MAD irrigation schedule.

The contrasting results in the open field (Harvest 3, where water-use efficiency was highest for the 20\% MAD treatment), could probably be explained by the high rainfall during the last three weeks of this regrowth cycle. This increased the amount of water considered in the WUE calculations of all treatments, but there was probably only a marginal increase in vegetative growth, especially for the treatments scheduled at higher MAD levels.

Compared to the $20 \%$ MAD treatment, up to $28 \%$ irrigation water could be saved in the open field trial (Harvest 1 ) by applying a $40 \%$ MAD level, without any significant reduction in essential oil yield (Table 8 ). In the rain shelter, between $13 \%$ (Harvest 1 ) and $22 \%$ (Harvest 2) water was saved by applying the $40 \%$ MAD treatment (Table 8). These differences between harvests in the rain shelter could be explained by seasonal effects, as most of the regrowth 
Table 7

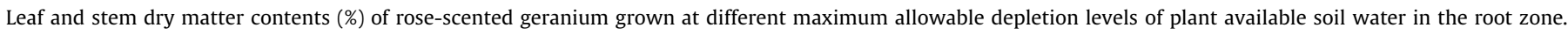

\begin{tabular}{|c|c|c|c|c|c|c|c|c|}
\hline \multirow[t]{3}{*}{ Treatments $\left(\mathrm{MAD}^{\mathrm{a}}\right)$} & \multicolumn{4}{|c|}{ Open field ${ }^{\mathrm{b}}$} & \multicolumn{4}{|c|}{ Rain shelter ${ }^{c}$} \\
\hline & \multicolumn{2}{|l|}{ Harvest 1} & \multicolumn{2}{|l|}{ Harvest 2} & \multicolumn{2}{|c|}{ Harvest 1} & \multicolumn{2}{|c|}{ Harvest 2} \\
\hline & Leaf & Stem & Leaf & Stem & Leaf & Stem & Leaf & Stem \\
\hline $20 \%$ & $18.40 c^{d}$ & $14.23 \mathrm{c}$ & $19.81 \mathrm{c}$ & $14.23 \mathrm{a}$ & $15.14 \mathrm{c}$ & $12.92 \mathrm{c}$ & $15.64 \mathrm{~b}$ & $12.42 \mathrm{~b}$ \\
\hline $40 \%$ & $19.33 \mathrm{~b}$ & $16.44 \mathrm{~b}$ & 20.79 b & $16.44 \mathrm{~b}$ & $17.30 \mathrm{~b}$ & $13.87 \mathrm{~b}$ & $16.71 \mathrm{ab}$ & $13.27 \mathrm{a}$ \\
\hline $60 \%$ & $20.34 \mathrm{a}$ & $16.68 \mathrm{~b}$ & $21.67 \mathrm{a}$ & $16.67 \mathrm{~b}$ & 17.71ab & $14.14 \mathrm{ab}$ & $17.02 \mathrm{a}$ & $13.45 \mathrm{a}$ \\
\hline $80 \%$ & $20.68 \mathrm{a}$ & 17.99 a & $21.61 \mathrm{ab}$ & $17.99 \mathrm{a}$ & $18.54 \mathrm{a}$ & $14.74 \mathrm{a}$ & $17.64 \mathrm{a}$ & $13.84 \mathrm{a}$ \\
\hline Grand mean & 19.64 & 16.33 & 20.97 & 16.33 & 17.18 & 13.92 & 16.75 & 13.25 \\
\hline CV (\%) & 2.12 & 1.74 & 2.51 & 1.74 & 4.05 & 3.78 & 4.15 & 3.98 \\
\hline $\operatorname{LSD}(P<0.05)$ & 0.66 & 0.45 & 0.84 & 0.45 & 1.11 & 0.84 & 1.11 & 0.84 \\
\hline
\end{tabular}

a MAD: maximum allowable depletion of plant available soil water.

b Harvests 1 and 2 in the open field trials were conducted in July and September 2005, respectively.

c Harvests 1 and 2 in the rain shelter were conducted in June and October 2006, respectively.

${ }^{d}$ Values in a column followed by the same letter do not differ significantly at $P<0.05$.
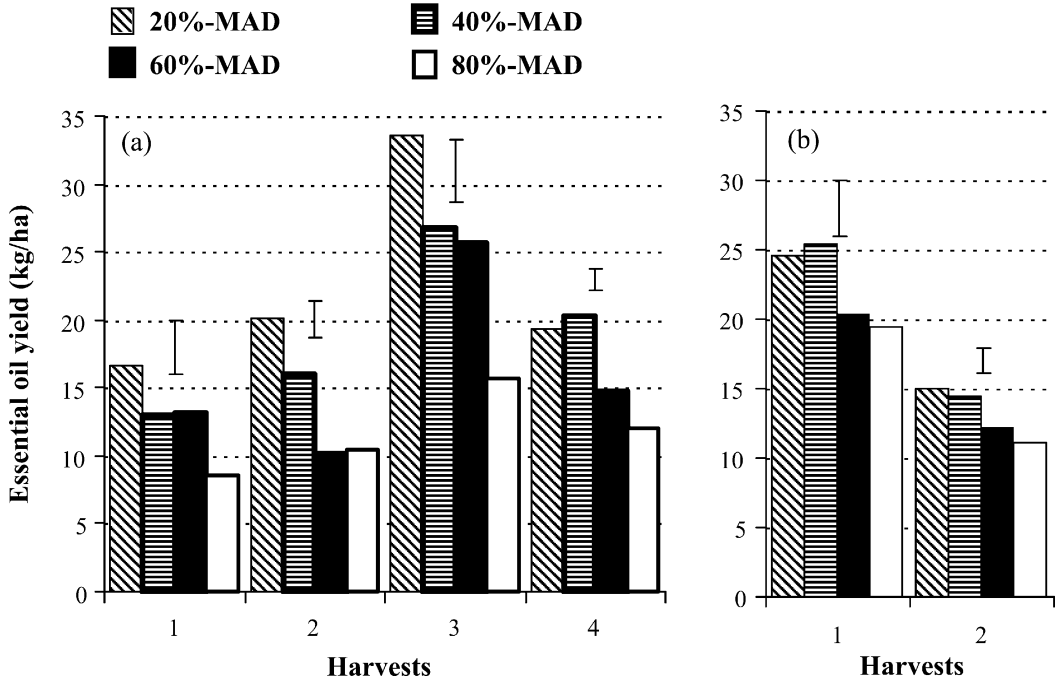

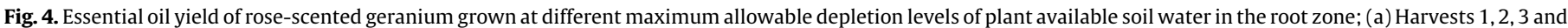

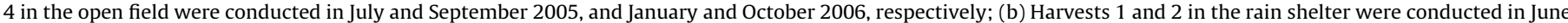
and October 2006, respectively; vertical bars are LSD (at $P<0.05$ ).
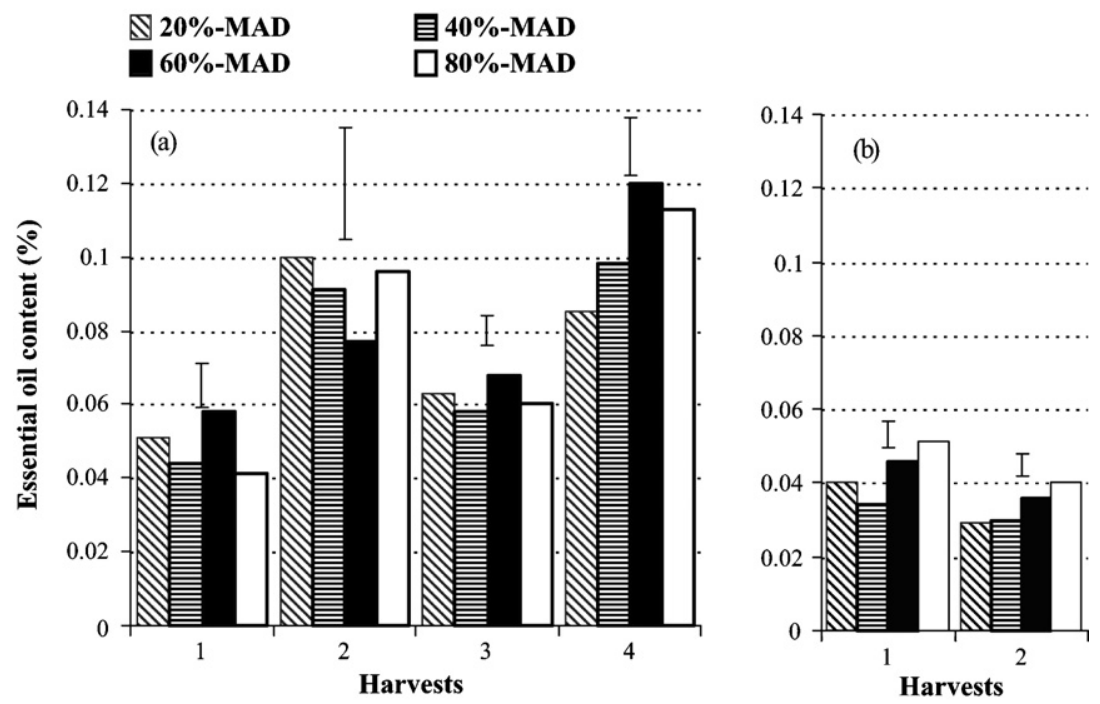

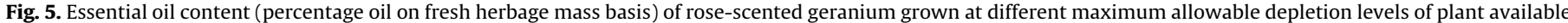

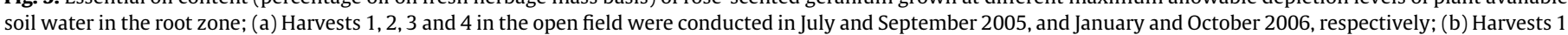
and 2 in the rain shelter were conducted in June and October 2006, respectively; vertical bars are LSD (at $P<0.05$ ).

Please cite this article in press as: Eiasu, B.K., et al., Rose-scented geranium (Pelargonium capitatum $\times$ P. radens) growth and essential oil yield response to different soil water depletion regimes. Agric. Water Manage. (2009), doi:10.1016/j.agwat.2009.01.012 


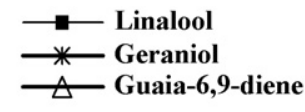

(a)

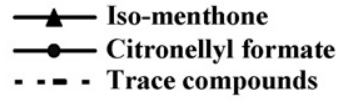

(b)

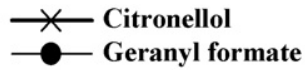

(c)

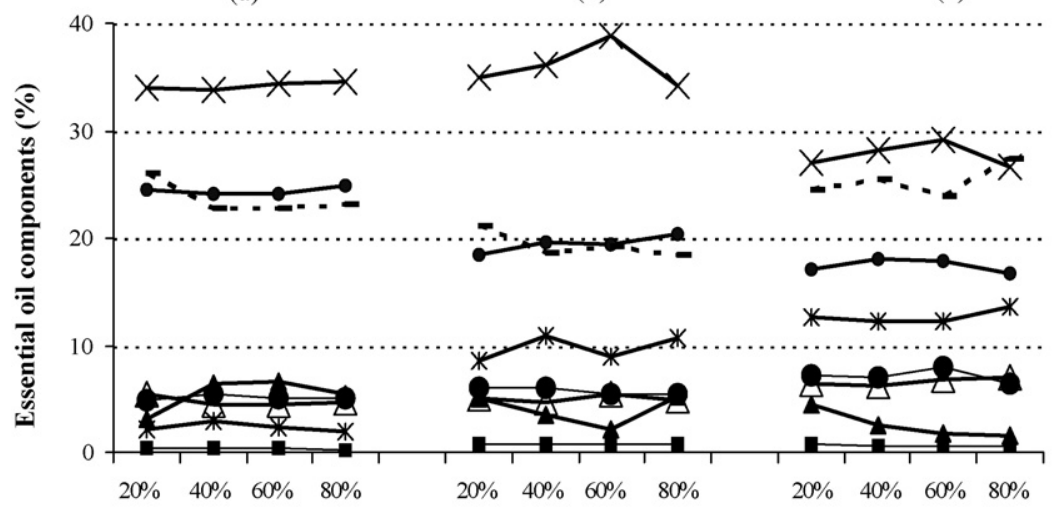

Maximum allowable depletion level

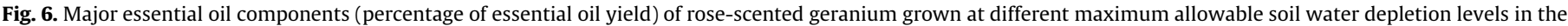
open field; Harvests 1 (a), 2 (b) and 3 (c) were conducted in July and September 2005, and January 2006, respectively.

Table 8

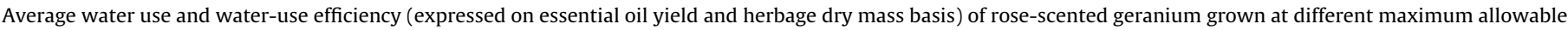
depletion levels of plant available soil water.

\begin{tabular}{|c|c|c|c|c|c|}
\hline \multirow[t]{2}{*}{$\mathrm{MAD}^{\mathrm{a}}$} & \multicolumn{2}{|l|}{ Water applied } & \multirow[t]{2}{*}{ Evapotranspiration (mm) } & \multicolumn{2}{|l|}{ Water-use efficiency } \\
\hline & Irrigation (mm) & Rainfall (mm) & & Oil $\left(\mathrm{g} \mathrm{ha}^{-1} \mathrm{~mm}^{-1}\right)$ & Dry herbage mass $\left(\mathrm{kg} \mathrm{ha}^{-1} \mathrm{~mm}^{-1}\right)$ \\
\hline \multicolumn{6}{|c|}{ Open field (Harvest 1, July 2005) } \\
\hline $20 \%$ & 485.3 & 0.0 & 476.6 & 34.9 & 11.5 \\
\hline $40 \%$ & 345.8 & 0.0 & 372.1 & 35.0 & 14.5 \\
\hline $60 \%$ & 310.6 & 0.0 & 310.0 & 42.2 & 13.8 \\
\hline $80 \%$ & 208.8 & 0.0 & 252.9 & 34.0 & 16.4 \\
\hline \multicolumn{6}{|c|}{ Open field (Harvest 3, January 2006) } \\
\hline $20 \%$ & 339.1 & 194.9 & 533.0 & 62.9 & 17.4 \\
\hline $40 \%$ & 281.0 & 203.2 & 488.3 & 52.6 & 15.8 \\
\hline $60 \%$ & 261.9 & 225.9 & 490.2 & 54.5 & 13.6 \\
\hline $80 \%$ & 171.0 & 214.9 & 383.0 & 40.8 & 12.6 \\
\hline \multicolumn{6}{|c|}{ Rain shelter (Harvest 1, June 2006) } \\
\hline $20 \%$ & 354.9 & 0.0 & 345.2 & 71.1 & 25.5 \\
\hline $40 \%$ & 306.2 & 0.0 & 332.0 & 76.7 & 28.6 \\
\hline $60 \%$ & 286.4 & 0.0 & 285.6 & 71.6 & 25.6 \\
\hline $80 \%$ & 174.3 & 0.0 & 238.1 & 81.6 & 27.6 \\
\hline \multicolumn{6}{|c|}{ Rain shelter (Harvest 2, October 2006) } \\
\hline $20 \%$ & 400.4 & 0.0 & 391.2 & 38.3 & 19.0 \\
\hline $40 \%$ & 310.5 & 0.0 & 335.8 & 43.1 & 22.2 \\
\hline $60 \%$ & 239.9 & 0.0 & 276.5 & 44.4 & 19.4 \\
\hline $80 \%$ & 176.3 & 0.0 & 226.3 & 48.9 & 20.0 \\
\hline
\end{tabular}

${ }^{\text {a }}$ MAD: maximum allowable depletion of plant available soil water.

period for Harvest 1 experienced cool temperatures (autumn/ winter), whereas the regrowth cycle for Harvest 2 experienced warm temperatures (spring).

\section{Conclusions and recommendations}

The present study indicated that rose-scented geranium roots are most active in the top $0.4 \mathrm{~m}$ soil layer. Herbage yield significantly declined when more than $40 \%$ of ASW (40\% MAD) was depleted from the root zone. An increase in leaf to stem ratio was a common response of plants to water stress conditions. In most cases essential oil yield increased with higher herbage yield and higher soil water status (lower MAD level). Water stress apparently increased essential oil content (percentage oil on fresh herbage mass basis), but it was too marginal to compensate for the yield loss due to reduced herbage yield. Composition of the seven principal essential oil components was not affected by irrigation scheduling regime. Essential oil composition variations among harvests indicated that geraniol and geranyl formate were inversely related to citronellol and citronellyl formate levels. For water saving, without a significant reduction in essential oil yield of rose-scented geranium produced on sandy clay loam soils, the authors recommend a maximum depletion level of $40 \%$ of ASW in the $0.8 \mathrm{~m}$ root zone.

\section{Acknowledgements}

The authors would like to acknowledge the Technology and Human Resource for Industry Programme (THRIP), Biosys Plant Extracts (Pty) Ltd., and Clive Teubes CC for funding the research, and Biosys Plant Extracts (Pty) Ltd. for essential oil distillation and GC analysis. 


\section{References}

Adams, R.P., 2004. Identification of Essential Oil Components by Gas Chromatography/Quadrupole Mass Spectroscopy. Allured Publ. Corp., Carol Stream, IL, USA.

Annandale, J.G., Benadé, N., Jovanovic, N.Z., Steyn, J.M., du Sautoy, N., 1999. Facilitating irrigation scheduling by means of soil water balance model. Water Research Commission, Report No. 753/1/99, Pretoria, South Africa.

Bhan, M.K., Dhar, A.K., Choudhary, D.K., Rekha, K., Balyan, S.S., Khan, S., Agarwal, S.G., Shawl, A.S., 2005. Geranium (Pelargonium sp. 'hybrid') essential oil in subtropical and temperate regions of Jammu and Kashmir. Flavour Fragrance J. 21, 527-530.

Conley, A.H., 1997. To be or not to be? South African irrigation at the crossroads. In: Kay, M., Franks, T., Smith, L. (Eds.), Water: Economics, Management and Demand. E and FN Spron, London, pp. 21-28.

Eiasu, B.K., Soundy, P., Steyn, J.M., 2008. High irrigation frequency and brief water stress prior to harvest enhances essential oil yield of rose-scented geranium (Pelargonium capitatum $\times$ P. radens). HortScience 43, 500-504.

Enright, W., 2003. From principle to implementation of integrated water resources management. In: McMahon, T., Basson, T. (Eds.), Proceedings of a Joint RSAAustralian Workshop on Water Resources Management, 31 March-5 April 2003. Lancemore Hill, Kilmore, Australia, pp. 7-19.

Fereres, E., Ceňa, F., 1998. Social benefits and environmental constraints of irrigation in an area of water scarcity. In: Kay, M., Franks, T., Smith, L. (Eds.), Water: Economics, Management and Demand. E and FN Spron, London, pp. 128-144.

Goldhamer, D.A., Fereres, E., Mata, M., Girona, J., Cohen, M., 1999. Sensitivity of a discrete plant and soil water status monitoring in peach trees subjected to deficit irrigation. J. Am. Soc. Hortic. Sci. 124, 437-444.

Jones, C.S., Cardon, Z.G., Czaja, A.D., 2003. A phylogenetic view of low-level CAM in Pelargonium (Geraniaceae). Am. J. Bot. 90, 135-142.

Kumar, S., Bahl, J.R., Bansal, R.P., Naqvi, A.A., 2001. Method for annual cropping of Pelargonium graveolens for rose-scented geranium essential oil in subtropical agroclimates. J. Hortic. Sci. Biotech. 76, 183-186.

Laio, F., Porporato, A., Ridolfi, L., Rodriguez-Iturbe, I., 2001. Plants in water-controlled ecosystem: active role of hydrologic processes and response to water stress: II. Probabilistic soil water dynamics. Adv. Water Resour. 24, 707-723.

Lambers, H., Chapin, F.S., Pons, T.L., 1998. Plant Physiological Ecology. Springer, New York, USA, pp. 154-204.

Lis-Balchin, M., 2002. Growing pelargonium in the garden, conservatory and for shows. In: Lis-Balchin, M. (Ed.), Geranium and Pelargonium: The Genera Geranium and Pelargonium. Taylor and Francis, London and New York, pp. 92-98.

Luthra, R., Singh, N., Sharma, S., 1991. Change in monoterpene content accompanying development of Cymbopogon winterianus (Jowitt) leaves. J. Essent. Oil Res. 3, 349-354.

Motsa, N.M., Soundy, P., Steyn, J.M., Learmonth, R.A., Mojela, N., Teubes, C., 2006. Plant shoot age and temperature effects on essential oil yield and oil composi- tion of rose-scented geranium (Pelargonium sp.) grown in South Africa. J. Essent. Oil Res. 18, 106-110.

MSTAT-C, 1991. A Microcomputer Program for Design Management and Analysis of Agronomic Research Experiments. Michigan State University, East Lansing, MI, USA.

Nieuwoudt, W.L., Backeberg, G.R., du Plessis, H.M., 2003. The value of water in the South African economy-a review. In: McMahon, T., Basson, T. (Eds.), Proceedings of a Joint RSA-Australian Workshop on Water Resources Management, 31 March-5 April 2003. Lancemore Hill, Kilmore, Australia, pp. 79-80.

Panda, R.K., Behera, S.K., Kashyap, P.S., 2004. Effective management of irrigation water for maize under stressed conditions. Agric. Water Manage. 66, 181-203.

Pandey, R.K., Maranville, J.W., Admou, A., 2000. Deficit irrigation and nitrogen effects on maize in a Sahelian environment: I. Grain yield and yield components Agric. Water Manage. 46, 1-13.

Qadir, M., Oster, J.D., 2004. Crop and irrigation management strategies for salinesodic soils and waters aimed at environmentally sustainable agriculture. Sci. Total Environ. 323, 1-19.

Rajeswara Rao, B.R., Kaul, P.N., Mallavarapu, G.R, Ramesh, S, 1996. Effect of seasonal climatic changes on biochemical yield and terponoid composition of rose-scented geranium (Pelargonium species). Biochem. Syst. Ecol. 24 627-635.

Salisbury, F.B., Ross, C.W., 1992. Plant Physiology. Wadswoth Inc., CA, USA, pp. 66-89.

SANDA (South African National Department of Agriculture), 2006. Rose Geranium Production. http://www.nda.agric.za/publications.[accessed on 25 October 2006].

Sangwan, N.S., Farooqi, A.H.A., Shabih, F., Sanguan, R.S., 2001. Regulation of essential oil production in plants. Plant Growth Regul. 34, 3-21.

Shand, M.J., Basson, M.S., 2003. South African water resources, availability, demands and strategic issues. In: McMahon, T., Basson, T. (Eds.), Proceedings of a Join RSA-Australian Workshop on Water Resources Management, 31 March-5 April 2003. Lancemore Hill, Kilmore, Australia, pp. 29-41.

Singh, M., 1999. Effect of soil water regime, nitrogen and modified urea materials on yield and quality of geranium (Pelargonium graveolens). J. Agric. Sci. 133, 203-207.

Singh, M., Chandrashekhara, G., Gansha Rao, R.S., Prakasa Rao, E.V.S., 1996. Effect of irrigation and nitrogen levels on herb and oil yield of geranium (Pelargonium sp.) under semi-arid tropical India. J. Essent. Oil Res. 8, 653-1653.

Tufekcioglu, A., Raich, J.W., Isenhart, T.M., Schultz, R.C., 1999. Fine root dynamics, coarse root biomass, root distribution, and soil respiration in a multispecies riparian buffer in Central Iowa. USA. Agrofor. Syst. 44, 163-174.

Weiss, E.A., 1997. Essential Oil Crops. Center of Agriculture and Biosciences (CAB) International, New York and UK, pp. 24-50.

Williams, C.A., Harborne, J.B., 2002. Photochemistry of the genus Pelargonium. In: Lis-Balchin, M. (Ed.), Geranium and Pelargonium: The Genera Geranium and Pelargonium. Taylor and Francis, London, p. 99. 